\title{
Family Victim Advocates: The Importance of Critical Job Duties
}

\author{
Teresa H. Young ${ }^{1}$ \\ Javonda Williams \\ Debra Nelson-Gardell \\ The University of Alabama
}

\begin{abstract}
Child advocacy centers across the United States intervened in more than 250,000 child abuse cases in 2011(National Children's Alliance, 2012). Understanding the work of family victim advocates is imperative to helping children and families in child abuse cases. In this exploratory study, we surveyed advocates and program directors from child advocacy centers (CACs) across the United States to compare their perceptions of the critical job duties of family victim advocates. Data analysis revealed that $\mathrm{CAC}$ directors rated the importance of these duties significantly higher than family victim advocates. Results suggest the need for additional training to ensure that family victim advocates understand the importance of critical job duties to meet the needs of children and families in child abuse cases.
\end{abstract}

Keywords: advocates, child advocacy centers, sexual abuse, children, victims, families

\section{Conselheiros de Proteção às Famílias em Situação de Violação: A Importância das Funções Críticas do Trabalho}

\begin{abstract}
RESUMO - Os centros de proteção e defesa da criança interviram em mais de 250 mil casos de abuso infantil em todos os Estados Unidos em 2011 (National Children's Alliance, 2012). Compreender o trabalho de profissionais de proteção e defesa de famílias em situação de violação é imprescindível para ajudar crianças e famílias em casos de abuso infantil. Neste estudo exploratório, realizamos uma pesquisa com os profissionais de proteção e defesa e com os diretores de programa dos centros de proteção e defesa da criança (CPDC) nos Estados Unidos para comparar suas percepções sobre as atividades fundamentais dos profissionais que realizam ações de proteção e defesa de famílias em situação de violação. A análise dos dados revelou que os diretores dos CPDC avaliaram de forma significativamente mais alta a importância do trabalho do que os próprios profissionais de defesa e proteção das famílias em situação de violência. Os resultados sugerem a necessidade melhorar a formação para garantir que os profissionais de defesa e proteção das famílias em situação de violência possam compreender a importância das funções de trabalho que são críticas e essenciais para atender às necessidades de crianças e famílias em casos de abuso infantil.
\end{abstract}

Palavras-chave: profissionais de proteção e defesa da família, centros de proteção e defesa da criança, abuso sexual, crianças, vítimas, famílias

Three million children are reported to be victims of child abuse each year in the United States (U.S. Department of Health \& Human Services Children's Bureau, 2011). In the 1980s, child advocacy centers evolved from the recognition that legal and child protective service agencies often used investigative processes that placed children and families at additional risk of emotional trauma (Jackson, 2004; Jones, Cross, Walsh, \& Simone, 2007). In response to federal and state legislation, many communities established child advocacy centers to provide a multidisciplinary response to reduce trauma experienced by children and families in child abuse cases.

In 2011, approximately 700 child advocacy centers located across the United States intervened in 267,000 child abuse cases (National Children's Alliance, 2012). Child advocacy centers provide a neutral, child-friendly

1 Endereço para correspondência: The University of Alabama, School of Social Work, 728, Magnolia Drive, Tuscaloosa, AL 3501, USA. E-mail: thyoung@crimson.ua.edu environment where trained professionals interview children suspected of being sexually or physically abused. The centers are also where family victim advocates provide education and support to parents and caregivers of these children. The job duties of family victim advocates impact the lives of child abuse victims as well as their parents and/or caregivers, siblings, extended family, and the overall community.

Given the current U.S. financial crisis affecting non-profit organizations, many child advocacy centers face dwindling resources as they deal with the complexity of child abuse investigations. Perceptions of the importance of job duties may impact decision-making and how $\mathrm{CAC}$ directors and advocates prioritize services to abused children and their families. This study provides useful information about how both CAC directors and family victim advocates perceive the importance of critical duties performed by advocates in child advocacy centers. This study was conducted in response to a request from the National Children's Advocacy Center in Huntsville, Alabama for information that could be used to 
expand and enhance training for family victim advocates working within child advocacy centers.

\section{Literature review}

While few existing studies specifically mention the work of family victim advocates in child advocacy centers (Corcoran, 2002), extensive research reflects the emotional and concrete needs of children and families in child abuse cases. Frequently researchers focus on the reactions of parents and the significance of parental support following disclosures of child sexual abuse (Kouyoumdjian, Perry, \& Hansen, 2009; Koverola, 2007; Shadoin \& Carnes, 2006). Following disclosure, family victim advocates provide services to children and non-offending parents and caregivers when multidisciplinary teams in child advocacy centers investigate the abuse allegations. In the following literature review, we therefore emphasize the research related to children and families following disclosure to determine which family victim advocate job duties are most critical.

We know from existing research that the responses of parents and helping professionals to children who disclose abuse can either assist or further traumatize child abuse victims (Lovett, 2004). Often viewed as a continuum, the process of disclosure may involve multiple steps as children frequently tell only a part of the abuse history and subsequently wait to see what happens before sharing more details of the abuse (Faller, Cordisco-Steele, \& NelsonGardell, 2010; Lovett, 2004). Therefore, child abuse victims and their families need continued support following the child's disclosure and throughout the investigation and prosecution of the case.

The establishment of child advocacy centers and implementation of a multidisciplinary approach improved how child abuse investigations are conducted overall (Cross, Jones, Walsh, Simone, \& Kolko, 2007; Newman, Dannelfelser, \& Pendelton, 2005; Smith, Witte, \& FrickerElhai, 2006). However, the systems used to investigate child abuse can still be emotionally damaging to parents and caregivers when they lack information or feel unsupported (Hill, 2005; Lovett, 2004). As a member of the multidisciplinary team, the primary role of family victim advocates is to provide education and support to children and families in child abuse cases.

Parents possess fundamental rights to the care, custody, and control of their children, and provide a primary source of support for their children (Lovett, 2004; Shadoin \& Carnes, 2006). Family victim advocates assist in building relationships between families and the investigative team by encouraging communication between families and law enforcement and child protective services agencies (Jenson, Jacobson, Unrau, \& Robinson, 1996). By engaging with families and other agencies throughout the investigation and prosecution of the child abuse case, family victim advocates become the voices of parents and children when multidisciplinary teams share information and coordinate services to families.

\section{Critical job duties}

National accreditation standards for child advocacy centers require designated, trained advocates to provide comprehensive, coordinated victim support and services including the following: provision of information regarding the dynamics of abuse and the coordinated multidisciplinary response; assistance in understanding victim rights and obtaining compensation; education about court process; criminal case updates; support and accompaniment to court proceedings; and assistance with referral to mental health/ medical treatment and other services (National Children's Alliance, 2012). The researcher designated these activities as critical job duties as prior research indicates how these tasks support and strengthen family and child functioning. In the following paragraphs, each of these job duties is discussed in relation to the work of family victim advocates in child advocacy centers.

\section{Court activities.}

Relying upon the literature, feedback from child advocacy center directors, and the principal investigator's prior experience, the researchers identified the following court activities used by advocates to support parents and children during the investigation and prosecution of the child abuse case:

- Provide updates to the family about the status of the criminal court case

- Assess the child and/or family's attitudes about the investigation and prosecution

- Provide information and/or support about the court process

- Accompany the child victim and family to court proceedings

Parents are the most important resource for their child following a disclosure of sexual abuse. In most cases, parents have the most contact with their child and know their child best. Parents also must deal with the long term consequences of the investigation and court process. Parents who lack information may transmit negative feelings to the child caused by their own not knowing or misconceptions about court procedures. A significant impact can be made on supporting child abuse victims and families simply by keeping parents informed and providing information about court processes (Bull, 2006).

In a study conducted by Hackett and Masson (2005), parents of child abuse victims valued most the professionals who helped them understand the child protection and criminal justice processes. Parents wanted a clear account of the actual events of the abuse in order to understand the risk and put protective measures into place. The overwhelming majority of parents expressed concerns that professionals did not understand what parents experienced (Hackett \& Masson, 2005). The study results emphasized the need to keep parents informed and recognized how the parents' responses to the abuse evolved during the investigative process. Family victim advocates play a key role in facilitating communication and information sharing between parents and 
other members of the multidisciplinary team. Because of the relationship that often develops between parents and family victim advocates, they are in a unique position to improve openness and communication among parents, child protective services, law enforcement, and prosecution agencies.

\section{Referral to mental health services and/or medical services.}

Family victim advocates also provide an important link in ensuring that parents and children receive referral to mental health and/or medical services following the child's disclosure of abuse.

Current research reflects the need for not only child abuse victims, but also their parents to be referred to mental health services to address their own potential for negative psychological reactions to their child's trauma (Schewe, 2008). The response of the person to whom the child discloses can significantly affect the psychological impact of sexual abuse on the child (Lovett, 2004). Because children often disclose abuse to parents (Hill, 2005; Jenson, et al, 1996), the emotional support they provide affects how their children adjust following disclosure. Existing research emphasizes children's need for emotional support by parents following a disclosure of sexual abuse (Avery, Massat, \& Lundy, 1998; Gries et al., 2000; Lovett, 2004).

Because child abuse statistics indicate that children are more likely to be sexually abused by males than females (National Center for Victims of Crime, 2014), we found that much of the research focused on the supportiveness provided by mothers. Unfortunately, the need for that support comes at a time when mothers may experience their own emotional crisis upon learning about the alleged abuse of their child. Disclosure of child sexual abuse often causes mothers to experience confusing, painful, and disjointed thoughts and feelings as well as unexpected social and economic stress (Bull, 2006; Corcoran, 2002). Research finds that mothers' reactions to a stressful event influence how children interpret that event and what the child focuses on and remembers of the event (Bull, 2006; Corcoran, 2002). Mothers who are secure in discussing a stressful event may enhance the child's ability to process the abuse, which enables the child to describe the circumstances of the abuse in later conversations with professional investigators.

The disclosure of sexual abuse often necessitates that mothers abused as children be referred for mental health services to address their own issues related to their own abuse histories. In a study of 105 mothers of sexually abused children, Davies, Seymour, and Read (2000) found that more than half the women in the study reported being sexually abused as children. Under these circumstances, mothers may vicariously re-experience trauma associated with their own sexual abuse (Davies, et al., 2000). Family victim advocates in child advocacy centers are responsible for referring both parents and children to mental health services.

In addition to mental health referrals, family victim advocates often are responsible for arranging for children to receive medical assessment and/or treatment. Often early on in child sexual abuse investigations, the medical examination can play an important role in the healing of the child and the reassurance of the child and family. An appropriate, multidisciplinary evaluation by the medical professional may be the determining factor in the outcome for the child, family, and society (Heger, Ticson, Velasquez, \& Bernier, 2002). For child sexual abuse cases where medical examination is required, the family victim advocate assists parents and caregivers by referring the child to medical personnel with specialized training and experience in medically evaluating sexually abused children (National Children's Alliance, 2012).

\section{Dynamics of child sexual abuse.}

Family victim advocates in child advocacy centers provide information to help parents understand the dynamics of child abuse. For example, advocates teach parents how to interpret signs and indicators of child sexual abuse versus normal childhood sexualized behaviors (Koverola, 2007). Also, helping parents recognize their own biases and behaviors can mediate the emotional effects of the abuse on the child and help parents develop appropriate expectations for their child's recovery. A study conducted by Kouyoumdjian, Perry, \& Hansen (2009) found that poor parental expectations for the child's adjustment following abuse were associated with an overall increase in the child's behavior problems. These results suggest that how children function emotionally following sexual abuse may be influenced by their parents' expectations. Having knowledgeable professionals, such as family victim advocates, available to provide information about the dynamics of child abuse helps parents cognitively restructure the environment to be more supportive of the child abuse victim (Schewe, 2008).

\section{Crisis intervention and on-going supportive services.}

Family victim advocates frequently provide crisis intervention and ongoing support services early in the investigative process when children and families are most vulnerable. Following the initial disclosure, the family must deal with immediate safety issues while coping with the emotional impact of the disclosure and the ensuing investigative process. Crisis intervention often begins when the parent brings the child for the initial interview at the child advocacy center. The opportunity to meet in-person with family members enables the advocate to establish rapport and begin building a connection between the family and the multidisciplinary team. Schewe (2008) found that children improved the most when services for parents focused on teaching the effects of exposure to violence and building effective support systems. The study indicated the need for parents to maintain a support system to address their own issues associated with the trauma of their child's abuse. Crisis intervention and on-going support services by family victim advocates help to assess the child and family's needs, 
reduce fear and anxiety, and improve access to appropriate services (Hill, 2005).

\section{Understanding the rights of crime victims.}

Family victim advocates provide information regarding the rights of crime victims to children and their family members and assist parents to apply for funding resources for counseling and other needs resulting from the abuse (National Children's Alliance, 2012). Funds available through victim compensation programs can alleviate the economic stress often experienced by parents of child abuse victims. Parents and children are often unfamiliar with these rights or may not understand them early in the investigative process. Therefore, family victim advocates must routinely and repeatedly, if needed, explain information regarding the legal rights and services to which child abuse victims and their families are entitled.

\section{Assisting families in obtaining concrete services.}

Prior research examined the factors that impact mothers in child abuse cases and their decisions about relationships and financial, vocational, relational, and residential issues (Massat \& Lundy, 1998). Many mothers face economic hardship when the child abuse offender is no longer in the home (Massat \& Lundy, 1998). In dealing with the stress following the child abuse disclosure, mothers may become overwhelmed by the additional financial burden when attempting to meet the family's basic needs. Family victim advocates provide support and information that assist parents in navigating the potentially, numerous and confusing agency systems parents encounter to secure concrete services (National Children's Alliance, 2012). Such concrete services include housing, public assistance, domestic violence intervention, and transportation that help stabilize the family during the investigation and/or prosecution of the child abuse case.

\section{Non-critical job duties}

In addition to the critical job duties supported by the literature, the accreditation standards of the National Children's Alliance also describes job duties intended to assist children and families and document the work of family victim advocates. Based upon the current published research and feedback from CAC directors, the researchers determined the following five job duties described in the standards of the National Children's Alliance (2012) to be less critical to the work of family victim advocates in child advocacy centers:

- Greet and/or provide orientation to children and families when they arrive at the CAC

- Secure transportation to CAC interviews or meetings

- Provide tours for child victim/family of the courtroom or courthouse,

- Document contacts with families and/or children
- Enter information case management information into computer

While the surveys asked family victim advocates and CAC directors to rate these job duties, this study focuses on the ratings of the critical job duties and does not include the results from the non-critical job duties.

The literature review for this study revealed the importance of understanding the work of family victim advocates and the need to be clear about the critical job duties that support child abuse victims and their parents or caregivers. Few existing studies discuss the actual job duties of family victim advocates or what aspects of their work are perceived as more important to service provision. We believed it was important to include CAC directors in the study since they are ultimately responsible for making these decisions. Given that we found no evidence to the contrary, for the purposes of the study we hypothesized that there would be no significant difference in how the CAC Directors and family victim advocates rated the importance of critical job duties.

\section{Methods}

The data collected, analyzed, and discussed in this paper were taken from a larger study that utilized a mixed methods approach to data collection from CAC directors and family victim advocates. This paper focuses on the quantitative data collected through CAC director and family victim advocate surveys. The Institutional Review Board at the University of Alabama reviewed and approved the project.

Researchers created, piloted, and delivered online surveys using the SuveyGizmo platform (http: www.surveygizomo. com/). The surveys were based upon the job duties for family victim advocates identified by the National Children's Alliance (NCA), a professional membership organization dedicated to helping local communities respond to allegations of child abuse and establishing the accreditation standards for child advocacy centers. The online surveys collected data from CAC directors and family victim advocates employed in child advocacy centers at the time of the survey. Recruitment was via email invitation issued through email lists belonging to each of four regional children's advocacy center directors responsible for approximately 700 child advocacy centers nationwide. At the request of the researchers, the regional children's advocacy center directors issued invitations and three reminders via email to the directors in each of these child advocacy centers. The invitation (and each subsequent reminder) included separate links to the CAC director survey and family victim advocate survey.

The number of family victim advocates working in each child advocacy center varies depending upon the needs of the community. The CAC directors who responded to the survey reported an average of 1.8 advocates employed in each of their child advocacy centers. Therefore, we calculated an average of 1.8 advocates in each of 700 child advocacy centers resulting in an estimated 1260 advocates potentially receiving the invitations and reminders to participate in the study. 
The introduction of the online survey included a statement providing informed consent information. If potential respondents chose to participate in the study, family victim advocates were able to click on the survey link, complete, and then submit the survey anonymously. Data from the online survey were collected using the SurveyGizmo platform with IP address tracking disabled to protect the participants against the researchers' access to information that, although unlikely, would lead to the researchers' ability to identify the participant.

\section{Study participants}

Study participants included both CAC directors and family victim advocates employed in child advocacy centers at the time of the survey.

\section{Child advocacy center directors.}

A total of 162 CAC directors responded and completed the online survey for an estimated response rate of $23 \%$. The researchers relied upon regional children's advocacy center to forward the study invitation and reminders to local CAC directors and inevitably a number of the directors failed to respond to the survey, which resulted in the lower than hoped for response rate.

The CAC directors provided the ethnicity of family victim advocates employed in their respective centers as well as their requirements for educational level and prior work experience for advocates. The directors employed an average of 1.8 advocates. In terms of race/ethnicity, directors were able to select more than one category in order to describe the advocates employed in their respective centers. A majority of the CAC directors (90\%) reported they employed whites, 25\% employed Hispanic/Latinos, 17\% employed African Americans, 6\% employed Native American Indians, and 3\% employed Asian/Pacific Islanders.

The minimum education level required by CAC directors for family victim advocates ranged from high school diploma (or GED) to graduate degree. The majority of CAC directors $(66 \%)$ required advocates to have a four-year college degree while other CAC directors (12\%) only employed advocates with graduate degrees. Approximately $17 \%$ of the CAC directors required persons working as advocates to have a high school diploma or equivalent, and $13 \%$ of the CAC directors required a two-year or Associate's college degree. In terms of previous years experience working with families and/or children, $33 \%$ of the CAC directors required advocates to have a minimum of two years experience while at least one year of experience was required by $24 \%$ of the CAC directors. A similar percentage of CAC directors (24\%) indicated that prior experience was not required for employment while $11 \%$ required advocates to have three prior years of experience working with families and/or children.

\section{Family victim advocates.}

The estimated response rate of family victim advocates was initially perceived as low. However, the researchers considered the effect of the two-tiered method of recruitment and the low return rate by the CAC directors. CAC directors were contacted first and asked to forward a link to the survey on to the advocates in their respective centers. Because 162 $\mathrm{CAC}$ directors responded to the survey, it is reasonable to assume that most of the CAC directors who responded also forwarded the survey to the advocates who work at their respective centers. At the rate of 1.8 advocates in each of these 162 centers, an estimated 292 family victim advocates actually received the invitation to respond to the online survey. A total of 248 family victim advocates responded to the online survey resulted in a response rate of $85 \%$.

For purposes of the study analysis, we chose to include only the 215 family victim advocates who completed the surveys in their entirety. Of those family victim advocates, $94 \%$ were female and $4 \%$ males. The remaining respondents (2\%) selected the option "prefer not to answer." The minimum age to participate in the study was 21 years. The ages of the family victim advocates who participated in the study ranged from 21-66 years with a mean of 38.1 years. Advocates were predominantly white $(82 \%)$ followed by African American (6\%), Hispanic/Latino (5\%), and other (4\%) including Asian/Pacific Islander, Native American/ Alaska Native, and multi-racial participants. Roughly half of the participants in the study $(51 \%)$ had undergraduate (four year) degrees, $27 \%$ had graduate degrees, $8 \%$ had some college but no degree, $7 \%$ had associate's degrees, and $4 \%$ had high school diplomas or general equivalency degrees.

The years of previous experience working with children and families prior to employment in the child advocacy center ranged from one $(18 \%)$ to 29 years $(1 \%)$ with a mean of 7.5 years. Roughly half of the participants in the study (47\%) reported five years or less experience working with families and/or children prior to being employed by the child advocacy center. Approximately $19 \%$ of the advocates reported 6-10 years prior experience, $13 \%$ had $11-15$ years prior experience, $6 \%$ had $16-20$ years prior experience, and $4 \%$ reported more than 20 years prior experience.

\section{Procedures}

Two separate surveys were designed to gather information from CAC directors and family victim advocates about the specific services provided by family victim advocates and how they rated the importance of their job duties. Aside from asking CAC directors to describe the advocates employed in each of their respective centers while asking advocates to provide specific demographic information, the items in the two surveys were essentially the same. Categories of inquiry were as follows: 1) assessment, 2) court-related, 3) service-related, 4) other duties, and 5) documentation. CAC directors and family victim advocates were asked to rate the importance of specific tasks related to each of these categories. 
A brief introduction to each category explained how the family victim advocate or someone else in their agency or community might perform the specific job duties described in the section. If the family victim advocate had responsibility for the specific task in the child advocacy center, then the study participant was asked to rate its importance. Using a Likert-like scale, participants rated the importance of each job duty according to the following: very important 4 , important 3 , moderate importance 2 , little importance 1 , and unimportant 0 . Participants could also select the option "not my/advocate's job 5."

Under the category of assessment, CAC directors and family victim advocates rated the importance of the following critical and non-critical job duties: 1) "Greet and/or provide an orientation to children and families when they arrive at the CAC", 2) "Interview parents and caregivers to provide crisis intervention and/or support", and 3) "Assessment of child/ family's attitudes about participation in the investigation/ prosecution." Under the category of court-related job duties, directors and advocates rated the importance of the following: 1) "Provide updates to the family about the status of the criminal court case", 2) "Provide information and/or support about the court process", 3) "Accompany child victim and/or family victim to court proceedings", and 4) "Provide tours for child victim and/or family of the courtroom/courthouse." Under the category of service-related job duties, directors and advocates rated the importance of the following: 1) "Secure transportation to interviews, court, treatment, and/or other case-related meetings", 2) "Assist families in obtaining concrete services (i.e., housing, food, public assistance), and 3) "Refer parents and children for mental health and/ or medical treatment, if not provided by CAC." Under the category of other job duties, directors and advocates rated the importance of the following: 1) "Help parents and caregivers understand the dynamics of child abuse through information sharing and discussion" and 2) "Help parents and caregivers understand crime victims' rights (for example, how to apply for victim compensation) through information sharing and/or discussion." Under the category of documentation, directors and advocates rated the importance of the following noncritical job duties: 1) "Documenting your contacts with families and/or children" and 2) "Entering information into a computer for purposes of case management/case tracking."

To measure participants' views of the importance of the critical job duties, we created a "critical job duties" scale. Overall, the online surveys included a total of fourteen job duties that the National Children's Alliance (2012) identified in their standards for victim advocacy and support. Using these victim advocacy standards and support from current published research (Hackett \& Masson, 2005; Schewe, 2005; Haig, Perry, \& Hansen, 2005; Heger et al, 2002), we identified nine critical job duties for family victim advocacy:

- Assist families in obtaining concrete services (i.e., housing, food, public assistance)

- Refer parents and children for mental health and/or medical treatment
- Help parents and caregivers understand the dynamics of child abuse through information sharing and/or discussion

- Accompany child victim and/or family to court proceedings

- Interview parents and caregivers to provide crisis intervention and/or support

- Provide information and/or support about the court process

- Assessment of child/family's attitudes about participation in the investigation/prosecution

- Provide updates to the family about the status of the criminal court case

- Helping parents understand the rights of crime victims

As previously stated, using a Likert-like scale participants rated the importance of each of these job duties according to the following: very important 4 , important 3 , moderate importance 2, little importance 1 , and unimportant 0 . Participants could also select the option not my job 5. For the analysis, we recoded not my job so that it was equivalent to 0 . The critical job duties scores were derived from the cumulative total of each participant's importance rating of the job duties.

The scale was interpreted with higher scores indicating more importance. For the family victim advocate survey, all items had significant item-total correlations.

The critical job duties measure obtained an overall Cronbach's Alpha coefficient of .676. Scores ranged from 0 to 19 with a mean of 15.89 and a standard deviation of 3.203 . For the CAC directors' survey, all items also had significant item-total correlations. The critical job duties measure for the CAC directors survey obtained an overall Cronbach's Alpha coefficient of .665. CAC director scores ranged from 0 to 36 with a mean of 29.47 and a standard deviation of 6.108 .

\section{Results}

Both the advocates and CAC Directors rated the importance of the critical job duties as moderate. Overall, the scores of each critical job duty ranged from 2.64 for the advocates to 3.74 and 2.73 to 3.61 on a four-point scale. See Table 1 for a complete listing of descriptive statistics for each job duty. In order to test the hypothesis that CAC directors and family victim advocates would rate the importance of critical job duties the same, the researchers conducted t-tests with SPSS Version 18.0 using two-tailed testing with the level of significance set at .05 .

Using the critical job duties scale, the researchers compared how CAC directors and family victim advocates rated critical job duties to determine whether there was a significant difference in how the CAC Directors and family victim advocates rated the importance of critical job duties. The independent sample t-test revealed that the CAC directors rated the critical job duties significantly higher that the family victim advocates $(\mathrm{t}=27.464, \mathrm{p}<.0001)$. 


\section{Discussion}

\section{Summary}

The researchers hypothesized that there would be no significant difference in how the CAC Directors and family victim advocates rated the importance of critical job duties. However, the results of the study indicated that CAC directors rated the importance of critical job duties significantly higher than the family advocates who participated in the study. This discrepancy between how CAC directors and family victim advocates rated the importance of critical job duties implies the need for family victim advocates to receive further training. As child advocacy centers continue to face issues of dwindling resources, including personnel, it is important that family victim advocates prioritize job duties to make the most of available time and energies. The results of this study imply the need for CAC directors and family victim advocates to be more aware of how each perceives the importance of the advocates' job duties as these perceptions impact decisionmaking in terms of service delivery to children and families in child abuse cases.

\section{Limitations}

The study involved a number of limitations. When we developed the surveys, we did not take into account that the standards of the National Children Alliance allowed child advocacy centers to provide victim advocacy services through linkage agreements with other agencies in the community so those child advocates were probably not included in the survey process. A number of CAC directors reported that victim advocacy services for their children and families were provided these linkage agreements with other organizations. Therefore, we did not include these family victim advocates in the study even though they perform many of the same job duties as family victim advocates in child advocacy centers.

As we discussed earlier, only a small percentage of CAC directors responded to the survey, which affects, of course, whether the results of this survey might be generalized to all CAC directors. We believe it may also be likely that if directors did not complete the survey that they did not forward the survey link to the family victim advocates working in their respective child advocacy centers. One factor that may have affected the response rate of the family victim advocates is that a consistent method for communicating directly with family victim advocates in child advocacy centers does not currently exist. There is not a nationwide organization for family victim advocates or any means for communicating directly with that specific group of professionals. We emailed the surveys to the CAC directors and relied upon each CAC director to forward the surveys to the family advocates in their respective child advocacy centers, but we do not know if they shared the survey invitation with the family victim advocates.

\section{Implications}

The current study has several implications for child advocacy center directors and regional children's advocacy centers responsible for oversight and training family victim advocates who work with children and their families in child abuse cases. The results indicated that CAC directors and family victim advocates perceive the importance of the advocates' critical job duties differently which prompts questions about why their perceptions differ and what impact does that have on decision making related to provision of services to children and families. These results indicate that $\mathrm{CAC}$ directors may need to provide more oversight and training to advocates in order to convey understanding about which services are more important and why. Being able to discern the importance of job duties is critical when making decisions related to service provision, especially when time and agency personnel are limited.

It may be that more advanced workshops and online courses could be beneficial to increase knowledge of family victim advocates about the importance of critical job duties. Presently basic and advanced trainings are available to family victim advocates in child advocacy centers (National Children's Advocacy Center, 2012). Advocacy training may need to clarify the importance of specific job duties and the provision of services that affect the children and families in child abuse cases. Understanding that specific tasks are more important to the well-being of children and families may also help family victim advocates establish priorities when they have limited time and resources. Training related to time management and decision-making around prioritization of client and agency needs may ultimately improve services to children and families in child abuse cases.

\section{Directions for further research}

The results of this study suggest a number of future directions for research aimed at understanding the work of family victim advocates in child advocacy centers and how their critical job duties affect outcomes for children and families in child abuse cases. In particular, prospective research needs to address the work of professionals from outside agencies who provide victim advocacy services through linkage agreements. These studies could be used to determine whether, and if so how, the services provided by outside agencies are similar or differ from the services provided by family victim advocates employed within the framework of the child advocacy centers. There is need to examine the training and supervision that these outside advocates and providers receive to ensure that children and families in child abuse cases receive services that meet their specific needs.

Family victim advocates within child advocacy centers also frequently share responsibilities with victim advocates employed within the court system. Further research needs to examine how critical job duties are shared among multiple agencies to ensure continuity of service delivery.

The current study relied upon regional children's advocacy centers to forward the survey link to CAC 
directors who were then asked to forward the survey link to family victim advocates. Methods that allow researchers to communicate directly with CAC directors regarding studies may also allow researchers to build relationships with directors and thus increase response rates to online surveys used in future research.

\section{References}

Avery, L., Massat, C.R., \& Lundy, M. (1998). The relationship between parent and child reports of parental supportiveness and psychopathology of sexually abused children. Child \& Adolescent Social Work Journal, 5(3), 187-205.

Bull, E. C. R. (2006). Child witness support and preparation: Are parents/caregivers ignored? Child Abuse Review, 15, 243-256.

Cross, T., Jones, L., Walsh W., Simone, M., \& Kolko, D. (2007). Child forensic interviewing in Children's Advocacy Centers. Child Abuse and Neglect, 31(10), 1031-1052.

Corcoran, J. (2002). The transtheoretical stages of change model and motivational interviewing for building maternal supportiveness in cases of sexual abuse. Journal of Child Sexual Abuse, 11(3), 1-17.

Davies, E., Seymour, F., \& Read, J. (2000). Children's and primary caretakers perceptions of the sexual abuse investigation process: A New Zealand example. Journal of Child Sexual Abuse, 9(2), 41-56.

Faller, K. C., Cordisco-Steele, L., \& Nelson-Gardell, D. (2010). Allegations of sexual abuse of a child: What to do when a single forensic interview isn't enough. Journal of Child Sexual Abuse, 19, 572-589.

Gries, L.T., Goh, D.S., Andrews, M.B., Gilbert, J., Praver, F., \& Stelzer, D.N. (2000). Positive reaction to disclosure and recovery from child sexual abuse. Journal of Child Sexual Abuse, 9(1), 29-51.

Hackett, S. \& Masson, H. (2005). Young people who have sexually abused: What do they (and their parents) want from professionals? Children \& Society, 20, 183-195.

Haig, K., Perry, A.R., Hansen, D.J. (2005). The role of adult expectations on the recovery of sexually abused children. Aggression and Violent Behavior, 10(4), 475-489.

Heger, A., Ticson, Velasquez, O., \& Bernier, R. (2002). Children referred for possible sexual abuse: Medical findings in 2384 children. Child Abuse \& Neglect, 26(6), 645-659.

Hill, S. (2005). Partners for protection: A future direction for child protection. Child Abuse Review, 14, 347-364.
Jackson, S. L. (2004). A USA national survey of program services provided by child advocacy centers. Child Abuse \& Neglect, 28, 411-421.

Jenson, J. M., Jacobsen, M., Unrau Y., \& Robinson, R. L. (1996). Intervention for victims of child sexual abuse: An evaluation of the children's advocacy center model. Child and Adolescent Social Work Journal, 13(2), 139-156.

Jones, L. M., Cross, T. P., Walsh, W. A., \& Simone, M. (2007). Do children's advocacy centers improve families' experiences of child sexual abuse investigations? Child Abuse \& Neglect, 31, 1069-1085.

Kouyoumdjian, H., Perry, A. R., \& Hansen, D. J. (2009). Nonoffending parent expectations of sexually abused children: Predictive factors and influence on children's recovery. Journal of Child Sexual Abuse, 18(1), 40-60.

Koverola, C. (2007). Perpetuating mother-blaming rhetoric: A commentary. Journal of child sexual abuse, 16(1), 137-143.

Lovett, B. B. (2004). Child sexual abuse disclosure: Maternal response and other variables impacting the victim. Child and Adolescent Social Work Journal, 21(4), 355-370.

Massat, C. R. \& Lundy, M. (1998). "Reporting costs" to nonoffending parents in cases of intrafamiliar child sexual abuse. Child Welfare, 77(4), 371-388.

National Children's Advocacy Center, Victim Advocacy Training (2012). Retrieved from http://www.nationalcac.org/events/ va-training.html

National Center for Victims of Crime (2014). Statistics on perpetrators of child sexual abuse. Retrieved from http://www. victimsofcrime.org/media/reporting-on-child-sexual-abuse/ statistics-on-perpetrators-of-csa

National Children's Alliance (2012). Membership Standards Victim Support and Advocacy. Retrieved from http://www. nationalchildrensalliance.org/index.php? $\mathrm{s}=76 \& \mathrm{cat}=5$

Newman, B. S., Dannenfelser, P. L., \& Pendleton, B. S. (2005). Child abuse investigations: Reasons for using child advocacy centers and suggestions for improvement. Child and Adolescent Social Work Journal, 22(2), 165-181.

Schewe, P. A. (2008). Direct service recommendations for children and caregivers exposed to community violence and domestic violence. Best Practices in Mental Health, 4(1), 31-47.

Shadoin, A. L. \& Carnes, C. N. (2006). Comments on how child protective services investigators decide to substantiate mothers for failure-to-protect in sexual abuse cases. Child Sexual Abuse, 15(4), 83-95.

Smith, D. W., Witte, T. H., \& Fricker-Elhai, A. E. (2006). Service outcomes in physical and sexual abuse cases: A comparison of child advocacy center-based and standard services. Child Maltreatment, 11(4), 354-360. 